\title{
Starter Culture Development from Lactic Acid Bacteria for Improved Nutritive Value of Linamarase Treated Cassava Peels
}

\author{
Adeleke Bartholomew Saanu ${ }^{*}$, Olaniyi Oladipo Oladiti \\ Department of Microbiology, Federal University of Technology, Akure, Nigeria
}

Email address:

microbade@yahoo.com(A.B. Saanu)

${ }^{*}$ Corresponding author

\section{To cite this article:}

Adeleke Bartholomew Saanu, Olaniyi Oladipo Oladiti. Starter Culture Development from Lactic Acid Bacteria for Improved Nutritive Value of Linamarase Treated Cassava Peels. Journal of Biomaterials. Vol. 2, No. 1, 2018, pp. 1-6. doi: 10.11648/j.jb.20180201.11

Received: March 12, 2018; Accepted: March 27, 2018; Published: April 18, 2018

\begin{abstract}
This study was design to develop starter culture from lactic acid bacteria for improved nutritive value of linamarase treated cassava peels. Isolation and identification of bacteria were carried out using standard microbiological and biochemical methods. The grated cassava peels was pre-treated by subjecting to pasteurization process. Pasteurized samples were inoculated with prepared bacterial inoculum and incubated at $37^{\circ} \mathrm{C}$ for 24 hours in a sealed vessel. The samples were withdrawn at interval for viable cell count. The proximate evaluation, mineral and anti-nutrient contents of the fermented and inoculated-fermented samples were determined using standard methods. From the fermented and inoculated-fermented cassava peels, the microbial loads increased from $1.5 \times 106$ to $26.1 \times 106 \mathrm{cfu} / \mathrm{ml}$ and $1.0 \times 106$ to $6.3 \times 106 \mathrm{cfu} / \mathrm{ml}$. The protein content showed a significant increase from 5.99 to $6.15 \%$ and 6.17 to $8.03 \%$ while crude fiber decreased from 14.33 to $13.01 \%$ and 14.46 to $11.47 \%$ respectively in fermented and inoculated-fermented samples. The cyanide content of the naturally fermented cassava peels decreased from 14.07 to $3.06 \mathrm{mg} / \mathrm{kg}$ while the inoculated-fermented cassava peels with linamarase-producing isolate showed a significant decrease in the cyanide content from 1.61 to $0.02 \mathrm{mg} / \mathrm{kg}$ respectively. Improvement in the nutritional composition with reduction in the anti-nutrient content of fermented and inoculated-fermented cassava peels suggest a promising and the application of these bacteria as biological tools in the production starter for the formulation of animal feeds.
\end{abstract}

Keywords: Cassava Peels, Lactic acid Bacteria, Solid State Fermentation, Starter Culture, Proximate and Antinutrient Content

\section{Introduction}

In some countries today mostly Nigeria, agriculture form the bedrock of her economy. The trend in quest for foods globally has cause the engagement of individual in various agricultural practices $[1,2]$. Tonnes of wastes are usually generated from homes, offices, industries, farms and market places annually [3]. An agricultural waste such as cassava peels is usually generated from the traditional processing of cassava tuber for garri and industrial starch production in Africa [4]. The cassava peels easily got rotten after some days of post-harvesting due to the microbial activities. Nigeria generated about 10 million tonnes of cassava waste annually. The indiscriminate and lack of control measure in disposal of this waste has resulted in release of obnoxious smell and health hazards $[5,6]$. Traditionally, cassava peels has been extensively used as resourceful animal feeds. The major constraint in utilization of cassava peels is due to its low protein, high fibre and accumulation of cyanogenic glycosides in the cell wall [7]. Adequate processing methods using fermentation techniques could help in bioconversion of this waste into utilizable products for both domestic and industrial use [8].

The fermentation process involving mono or mixed cultures of microorganisms stand as a useful tool in improvement of the nutritional quality and safety of the final products. The use of single or mixed starter has been used in fermentation processes for the improvement in the nutritional values and degradation on toxic element such as cyanide in most foods [9, 10]. This is brought about the secretion of extracellular linamarase enzyme as precursor for the cleavage of linamarin - the cyanogenic 
glycosides that present in cassava and cassava peels [11]. The activities of microorganisms in most fermented foods have resulted in biosynthesis of vitamins, essential amino acids and proteins thereby improving the nutritional quality, fibre digestibility and degrading anti-nutritional factors [12].

Selection of desired microbial inoculum has been used in food industries in enhancing the nutritional quality of cassava and cassava wastes [13]. Lactic acid bacteria fermentation has been identified as an inexpensive tool for increasing the protein level of substrates in a solid fermentation technique. Different microorganisms have been used in fermentation of cassava and cassava peels either as natural microflora or inoculants. Some of these microorganisms are Bacillus spp, Leuconostoc spp, Klebsiella spp, Corynibacterium spp, Lactobacillus spp, Aspergillus spp, Candida spp and Geotrichum spp [14, 15]. Development of starter in fermentation process for a desirable products formation has been found as less inexpensive means, cost effective, reduce fermentation time as well as guarantee product safety $[16,17]$.

Therefore, there is need to apply modern biotechnological techniques in improving traditional food processing technology using starter. However, the improvement in the nutritional content of cassava peels inoculated with starter with ability of producing linamarase enzyme suggest its application for industrial use as main substrate in animal feed formulation.

\section{Materials and Methods}

\subsection{Sample Collection}

Fresh cassava peels wastes were collected from different cassava processing (peeling) site from different locations in Akure, Nigeria.

\subsection{Fermentation of Cassava Peels}

Cassava peels wastes were fermented for a period of 120 hours at room temperature $\left(28 \pm 2^{\circ} \mathrm{C}\right)$. Isolation of bacteria using De Mann Rogosa and Sharpe (MRS) media was carried out using serial dilution and pour plate methods. The serial dilution was carried out up to $10^{6}$ dilution factor; $0.1 \mathrm{ml}$ of the diluent was aseptically dispensed into Petri dishes, pour plated with already sterilized molten media. The plates were incubated anaerobically for $24-36$ hours at $30^{\circ} \mathrm{C}$. After incubation, the colonies on the plates were counted and recorded as colony forming unit per milliliter $(\mathrm{cfu} / \mathrm{ml})$. The pure cultures were kept on slant and stored in refrigerator at $4^{\circ} \mathrm{C}$. Representatives of the different purified colonies were subjected to various cultural, morphological and biochemical analyses. Identification was based on Bergey's Manual of
Determinative Bacteriology $9^{\text {th }}$ Edition [18] and Bergey's Manual of Systematic Bacteriology [19].

\subsection{Collection of Linamarase Screened Isolates}

The linamarase screened isolates were collected from culture bank in an enclosed ice-pack bag at Microbiology laboratory, the Federal University of Technology, Akure, Nigeria and then stored for further use.

\subsection{Inoculum Preparation}

This was done according to the method of Adeleke et al. [3]. Fifty milliliter (50ml) de Mann Rogosa and Sharpe (MRS) broth was prepared in conical flask, sterilized and then inoculated with different inoculum concentration of the bacterial isolates with the ability of secreting extracellular linamarase enzyme.

\subsection{Inoculum Preparation}

Two hundred and fifty milliliters $(250 \mathrm{ml})$ inoculum suspension of the linamarase-producing bacterial isolates was prepared from a 24-hour old broth culture. Varied concentrations $(1000 \mu \mathrm{g} / \mathrm{l}, 10000 \mu \mathrm{g} / \mathrm{l}, 15000 \mu \mathrm{g} / \mathrm{l}$ and $20000 \mu \mathrm{g} / \mathrm{l})$ of the broth culture were pipetted using micropipette at different calibration prior inoculation of the pasteurized cassava peels.

\subsection{Treatment of Cassava Peels and Viable Cell Determination}

This was carried out according to the method of Adeleke et al. [3]. Two hundred grammes $(200 \mathrm{~g})$ grated cassava peels was weighed, pasteurized and allowed to cool; and then aseptically dispensed into different sterilized fermenting flasks. The samples were inoculated with standardized different inoculum concentrations of the individual microorganisms without dewatering the grated samples and then incubated at room temperature $\left(30 \pm 2^{\circ} \mathrm{C}\right)$ for 96 hours (anaerobically). The bacterial cell viability were monitored on the daily basis by aseptically taken $1.0 \mathrm{~g}$ from the inoculated fermented sample and serially diluted for each day of fermentation on appropriate bacteriological medium.

\subsection{Proximate Analysis}

The proximate analysis of the fermented and inoculatedfermented cassava peels were monitored according to the method of AOAC [20]. The proximate parameter determined were moisture, ash, fat, crude fibre and protein content. The total carbohydrate content was obtained by subtraction of mentioned component from 100.

$$
\text { Total carbohydrate }=100-(\% \text { moisture }+\% \text { ash }+\% \text { fat }+\% \text { crude fibre }+\% \text { protein }) .
$$

\subsection{Antinutrient Determination}

The cyanide content of the fermented and inoculatedfermented samples was determined according to the method of Ahaotu et al. [21]. Two grams (2g) of the sample were weighed into a flask and $100 \mathrm{ml}$ of distilled water was added

to it and allow hydrolyzing for 1 hour. Ten milliltres $(10 \mathrm{ml})$ of $2.5 \% \mathrm{NaOH}$ was measured and carefully and poured into the sample holder. The Soxhlet apparatus was set up and was distilled into the sample holder containing $2.5 \% \mathrm{NaOH}$ until $70 \mathrm{ml}$ was collected. It was carefully transferred into $100 \mathrm{ml}$ volumetric flask and the sample holder rinsed with distilled 
water successfully and also poured into volumetric flask. It was made up to the mark. Twenty five millilitres $(25 \mathrm{ml})$ of the distillate was pipetted into a conical flask, $2 \mathrm{ml}$ of $6 \mathrm{M}$ $\mathrm{NH}_{4} \mathrm{OH}$ was added and $0.5 \mathrm{ml}$ of $10 \%$ potassium iodine solution was added and titrated against $0.02 \mathrm{M} \quad \mathrm{AgNO}_{3}$ solution. The blank was also titrated until the end point is indicated by a faint but permanent turbidity.

\subsection{Data Analysis}

One way analysis of variance and Duncan's Multiple Range Test were used to analyze data.

\section{Results}

\subsection{Total Bacterial Counts}

Table 1 shows the total bacterial counts from both fermented and inoculated-fermented cassava peels. The bacterial counts increased from 15.0 to $187.0 \mathrm{cfu} / \mathrm{ml}$ and 10.0 to $63.0 \mathrm{cfu} / \mu \mathrm{ml}$ for fermented and inoculated-fermented cassava peels with increase in fermentation time respectively. The bacteria isolated were Lactobacillus plantarum, $L$. bulgaricus, L. casei and L. fermentum (Table 2).

\subsection{Viable Cell Counts}

Figure 1 shows the viability of the cell in the inoculatedfermented cassava peels. The cell counts increased with varied inoculum concentration introduced into the medium with fermentation time. The highest viable counts $112.0 \mu \mathrm{g} / \mathrm{ml}$ with $20000 \mu \mathrm{L}$ bacterial inoculum was recorded on the day 3 while the lowest $10 \mu \mathrm{g} / \mathrm{ml}$ with $1000 \mu \mathrm{L}$ was obtained at day 1 of the fermentation process. There was no significant difference $(p<0.05)$ in the viable cells obtained from the sample inoculated with different inoculum concentration at day 1 .

\subsection{Proximate Composition of Fermented and Inoculated-Fermented Cassava Peels}

Tables 3, 4 and 5 show the percentage proximate composition of fermented and inoculated-fermented cassava peels at 24, 72 and 120 hours. The protein, fat, ash and moisture contents of the samples increased while the crude fibre and carbohydrate contents decreased with fermentation time. The protein, fat and ash contents were significantly here at the 72 hours of the fermentation. The protein, fat and ash contents increased from 6.24 to $10.46 \%, 1.45$ to $3.85 \%$ and 0.65 to $1.82 \%$ respectively. The carbohydrate and crude fibre decreased from 9.77 to $5.67 \%$ and 13.34 to $10.21 \%$.

Table 1. Microbial counts.

\begin{tabular}{lll}
\hline \multirow{2}{*}{ Fermentation time } & Samples & IFS \\
\cline { 2 - 3 } & FS & $1.0 \times 10^{6}$ \\
\hline 1 & $1.5 \times 10^{6}$ & $1.6 \times 10^{6}$ \\
2 & $3.0 \times 10^{6}$ & $3.8 \times 10^{6}$ \\
3 & $20.5 \times 10^{6}$ & $5.5 \times 10^{6}$ \\
4 & $26.1 \times 10^{6}$ & $6.3 \times 10^{6}$ \\
5 & $18.7 \times 10^{6}$ & \\
\hline
\end{tabular}

Key: FS - Fermented sample, IFS - Inoculated fermented sample.

Table 2. Biochemical and morphological characterization of bacteria isolates.

\begin{tabular}{|c|c|c|c|c|c|c|c|c|c|}
\hline \multirow{2}{*}{ Isolates code } & \multirow{2}{*}{ Cell shape } & \multirow{2}{*}{ Cell arrangement } & \multirow{2}{*}{ Gram reaction } & \multirow{2}{*}{ Catalase } & \multirow{2}{*}{ Motility } & \multicolumn{3}{|c|}{ Sugar fermentation } & \multirow{2}{*}{ Probable isolates } \\
\hline & & & & & & Glucose & Lactose & Maltose & \\
\hline $\mathrm{TP}$ & $\mathrm{R}$ & $\mathrm{Ch}$ & + & - & + & $\mathrm{AG}$ & $\mathrm{AG}$ & $\mathrm{AG}$ & Lactobacillus bulgaricus \\
\hline TS & $\mathrm{R}$ & $\mathrm{Ch}$ & + & - & + & $\mathrm{AG}$ & $\mathrm{AG}$ & $\mathrm{AG}$ & L. fermentum \\
\hline TA & $\mathrm{R}$ & $\mathrm{Ch}$ & + & - & + & $\mathrm{AG}$ & $\mathrm{AG}$ & $\mathrm{Ag}$ & L. plantarum \\
\hline TR & $\mathrm{R}$ & $\mathrm{Ch}$ & + & - & + & $\mathrm{Ag}$ & $\mathrm{Ag}$ & $\mathrm{Ag}$ & L. casei \\
\hline TY & $\mathrm{R}$ & $\mathrm{Ch}$ & + & + & + & $\mathrm{AG}$ & $\mathrm{AG}$ & $\mathrm{AG}$ & L. plantarum \\
\hline
\end{tabular}

Key: $\mathrm{R}=$ rod, $\mathrm{Ch}=$ chains, $-=$ negative, $+=$ positive, $\mathrm{AG}=$ acid and gas production, $\mathrm{Ag}=$ Acid production but no gas

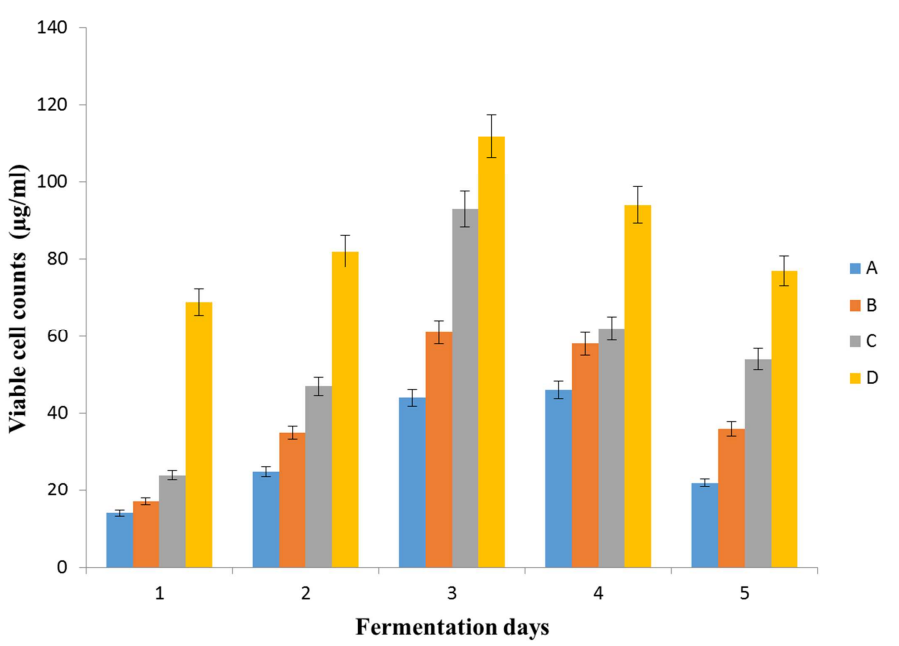

Key: $\mathrm{A}=1000 \mu \mathrm{g} / \mathrm{ml}, \mathrm{B}=10000 \mu \mathrm{g} / \mathrm{ml}, \mathrm{C}=15000 \mu \mathrm{g} / \mathrm{ml}, \mathrm{D}=20000 \mu \mathrm{g} / \mathrm{ml}$

Figure 1. Viable cell counts. 
Table 3. Percentage proximate composition of fermented and inoculated-fermented cassava peels at 24 hours.

\begin{tabular}{llllll}
\hline \multirow{2}{*}{ Proximate } & \multirow{2}{*}{ Control } & \multicolumn{4}{l}{ Inoculum concentration $(\boldsymbol{\mu g} / \mathbf{m l})$} \\
\cline { 3 - 6 } & & $\mathbf{1 0}^{\mathbf{3}}$ & $\mathbf{1 0}^{\mathbf{4}}$ & $\mathbf{1 . 5 \times 1 \mathbf { 1 0 } ^ { 4 }}$ & $\mathbf{2 . 0 \times 1 0 ^ { 4 }}$ \\
\hline Moisture content & $68.17 \pm 0.28^{\mathrm{a}}$ & $68.03 \pm 0.06^{\mathrm{a}}$ & $68.29 \pm 0.21^{\mathrm{a}}$ & $69.12 \pm 0.09^{\mathrm{b}}$ & $68.21 \pm 0.11^{\mathrm{a}}$ \\
Ash & $0.66 \pm 0.04^{\mathrm{a}}$ & $0.66 \pm 0.03^{\mathrm{a}}$ & $0.71 \pm 0.02^{\mathrm{a}}$ & $0.82 \pm 0.07^{\mathrm{b}}$ & $0.84 \pm 0.09^{\mathrm{b}}$ \\
Fat & $1.51 \pm 0.06^{\mathrm{a}}$ & $1.53 \pm 0.01^{\mathrm{a}}$ & $1.54 \pm 0.04^{\mathrm{a}}$ & $1.56 \pm 0.05^{\mathrm{a}}$ & $5.00 \pm 0.10^{\mathrm{b}}$ \\
Crude protein & $6.09 \pm 0.03^{\mathrm{a}}$ & $6.24 \pm 0.04^{\mathrm{a}}$ & $6.95 \pm 0.14^{\mathrm{b}}$ & $7.30 \pm 0.53^{\mathrm{c}}$ & $7.94 \pm 0.09^{\mathrm{c}}$ \\
Crude fibre & $14.17 \pm 0.10^{\mathrm{c}}$ & $14.22 \pm 0.15^{\mathrm{c}}$ & $13.34 \pm 0.23^{\mathrm{b}}$ & $11.54 \pm 0.09^{\mathrm{a}}$ & $11.36 \pm 0.41^{\mathrm{a}}$ \\
Carbohydrate content & $9.39 \pm 0.15^{\mathrm{c}}$ & $9.31 \pm 0.21^{\mathrm{bc}}$ & $9.16 \pm 0.22^{\mathrm{bc}}$ & $9.03 \pm 0.04^{\mathrm{b}}$ & $6.66 \pm 0.25^{\mathrm{a}}$ \\
\hline
\end{tabular}

Data are represented as mean \pm standard deviation with the same superscript across the row are not significantly different $(\mathrm{p}<0.05)$.

Key: $\mathrm{a}, \mathrm{b}$ and $\mathrm{c}$ (superscript) $=$ treatment mean difference

Table 4. Percentage proximate composition of fermented and inoculated-fermented cassava peels at 72 hours.

\begin{tabular}{llllll}
\hline \multirow{2}{*}{ Proximate } & \multirow{2}{*}{ Control } & \multicolumn{4}{l}{ Inoculum concentration $\mathbf{( \mu \mathbf { g } / \mathbf { m l } )}$} \\
\cline { 3 - 6 } & & $\mathbf{1 0}^{\mathbf{3}}$ & $\mathbf{1 0}^{\mathbf{4}}$ & $\mathbf{1 . 5}^{\mathbf{1 0}} \mathbf{1 0}^{\mathbf{4}}$ & $\mathbf{2 . 0 \times 1 0}^{\mathbf{4}}$ \\
\hline Moisture content & $68.34 \pm 0.07^{\mathrm{a}}$ & $68.56 \pm 0.23^{\mathrm{a}}$ & $69.00 \pm 0.13^{\mathrm{b}}$ & $69.09 \pm 0.03^{\mathrm{bc}}$ & $69.29 \pm 0.07^{\mathrm{c}}$ \\
Ash & $0.63 \pm 0.09^{\mathrm{a}}$ & $0.68 \pm 0.05^{\mathrm{a}}$ & $0.73 \pm 0.09^{\mathrm{ab}}$ & $0.73 \pm 0.01^{\mathrm{ab}}$ & $0.86 \pm 0.08^{\mathrm{c}}$ \\
Fat & $1.52 \pm 0.09^{\mathrm{a}}$ & $1.61 \pm 0.03^{\mathrm{a}}$ & $1.64 \pm 0.05^{\mathrm{a}}$ & $1.61 \pm 0.02^{\mathrm{a}}$ & $4.57 \pm 0.54^{\mathrm{b}}$ \\
Crude protein & $6.15 \pm 0.13^{\mathrm{a}}$ & $7.35 \pm 0.19^{\mathrm{b}}$ & $7.54 \pm 0.11^{\mathrm{b}}$ & $7.90 \pm 0.07^{\mathrm{c}}$ & $8.03 \pm 0.03^{\mathrm{c}}$ \\
Crude fibre & $14.59 \pm 0.29^{\mathrm{d}}$ & $13.07 \pm 0.24^{\mathrm{c}}$ & $12.35 \pm 0.35^{\mathrm{b}}$ & $11.99 \pm 0.10^{\mathrm{ab}}$ & $11.47 \pm 0.42^{\mathrm{a}}$ \\
Carbohydrate content & $8.77 \pm 0.44^{\mathrm{b}}$ & $8.73 \pm 0.22^{\mathrm{b}}$ & $8.74 \pm 0.22^{\mathrm{b}}$ & $8.68 \pm 0.13^{\mathrm{b}}$ & $5.79 \pm 0.80^{\mathrm{a}}$ \\
\hline
\end{tabular}

Data are represented as mean \pm standard deviation with the same superscript across the row are not significantly different $(\mathrm{p}<0.05)$.

Key: a, b, c and d (superscript) $=$ treatment mean difference

Table 5. Percentage proximate composition of fermented and inoculated-fermented cassava peels at 120 hours.

\begin{tabular}{|c|c|c|c|c|c|}
\hline \multirow{2}{*}{ Proximate } & \multirow{2}{*}{ Control } & \multicolumn{4}{|c|}{ Inoculum concentration $(\mu \mathrm{g} / \mathrm{ml})$} \\
\hline & & $10^{3}$ & $10^{4}$ & $1.5 \times 10^{4}$ & $2.0 \times 10^{4}$ \\
\hline Moisture content & $68.56 \pm 0.34^{\mathrm{a}}$ & $68.43 \pm 0.32^{\mathrm{a}}$ & $68.38 \pm 0.23^{\mathrm{a}}$ & $68.35 \pm 0.05^{\mathrm{a}}$ & $68.42 \pm 0.05^{\mathrm{a}}$ \\
\hline Ash & $0.65 \pm 0.09^{\mathrm{a}}$ & $0.67 \pm 0.06^{\mathrm{a}}$ & $1.11 \pm 0.09^{\mathrm{b}}$ & $1.56 \pm 0.06^{\mathrm{c}}$ & $1.82 \pm 0.07^{\mathrm{d}}$ \\
\hline Fat & $1.45 \pm 0.10^{\mathrm{a}}$ & $1.52 \pm 0.05^{\mathrm{a}}$ & $1.64 \pm 0.09^{\mathrm{ab}}$ & $1.79 \pm 0.19^{\mathrm{b}}$ & $3.85 \pm 0.15^{\mathrm{c}}$ \\
\hline Crude protein & $6.24 \pm 0.16^{\mathrm{a}}$ & $7.57 \pm 0.11^{\mathrm{b}}$ & $8.03 \pm 0.33^{\mathrm{bc}}$ & $8.43 \pm 0.43^{\mathrm{c}}$ & $10.46 \pm 0.61^{\mathrm{d}}$ \\
\hline Crude fibre & $13.34 \pm 0.47^{\mathrm{d}}$ & $12.32 \pm 0.20^{\mathrm{c}}$ & $11.68 \pm 0.46^{\mathrm{bc}}$ & $10.87 \pm 0.79^{\mathrm{ab}}$ & $10.21 \pm 0.48^{\mathrm{a}}$ \\
\hline Carbohydrate content & $9.77 \pm 0.29^{\mathrm{c}}$ & $9.48 \pm 0.34^{\mathrm{bc}}$ & $9.34 \pm 0.41^{\mathrm{bc}}$ & $9.00 \pm 0.72^{\mathrm{b}}$ & $5.67 \pm 0.13^{\mathrm{a}}$ \\
\hline
\end{tabular}

Data are represented as mean \pm standard deviation with the same superscript across the row are not significantly different $(\mathrm{p}<0.05)$.

Key: a, b, c, and d (superscript) $=$ treatment mean difference

\subsection{Antinutrient Contents of Fermented and Inoculated-Fermented Cassava Peels}

Table 6 shows the antinutrient content of the fermented and inoculated-fermented cassava peels. The anitinutrient content of the fermented was higher when compared with the inoculated-fermented sample. The cyanide content of the naturally fermented cassava peels decreased from 14.07 to $3.06 \mathrm{mg} / \mathrm{kg}$ while the inoculated-fermented cassava peels also decreased significantly $(\mathrm{p}<0.05)$ in cyanide content from 1.61 to $0.02 \mathrm{mg} / \mathrm{kg}$ respectively as the days of fermentation progresses.

Table 6. Anti-nutrient content of fermented and inoculated-fermented cassava peels.

\begin{tabular}{llllll}
\hline \multirow{2}{*}{ Sample } & \multicolumn{6}{l}{ Days of fermentation $(\mathbf{m g} / \mathbf{k g})$} \\
\cline { 2 - 6 } & $\mathbf{1}$ & $\mathbf{2}$ & $\mathbf{3}$ & $\mathbf{4}$ & $\mathbf{5}$ \\
\hline Fermented & $14.07^{\mathrm{e}}$ & $11.00^{\mathrm{d}}$ & $8.54^{\mathrm{c}}$ & $5.00^{\mathrm{b}}$ & $3.06^{\mathrm{a}}$ \\
Treated-Fermented & $1.61^{\mathrm{b}}$ & $1.12^{\mathrm{b}}$ & $1.07^{\mathrm{b}}$ & $0.06^{\mathrm{a}}$ & $0.02^{\mathrm{a}}$ \\
\hline
\end{tabular}

Data are represented as mean with the same superscript across the row are not significantly different $(\mathrm{p}<0.05)$.

Key: a, b, c, d and e (superscript) $=$ treatment mean difference

\section{Discussions}

Different microorganisms were isolated from both fermented and treated-fermented cassava peels. The isolates were majorly lactic acid bacteria. The dominance of these microorganisms might be due to their ability to tolerate acidic and low $\mathrm{pH}$ condition in the fermentation medium. Isolation of different microorganisms from cassava wastes has been reported [3, 22, 23].

The increase in the bacterial counts might be attributed to the ability of the microorganisms to utilize the available nutrients in the fermentation medium, source of sample collection and methods employed in the fermentation process. The low in total viable cell counts observed in the treated-fermented sample when compared with the fermented sample might be attributed to subject under controlled fermentation. The variation in the bacterial counts might be due to the genetic make-up of the microorganisms, ability of the microorganisms utilizing sugars as sole carbon source and the environmental condition of the fermentation medium. The occurrence of these microorganisms might be due to their ability to secrete organic acids (acetic) into the fermentation medium inhibiting the other microorganisms 
which cannot grow in an acidic medium and their survival under acidic environment. The increase in number of viable cells could be due to their genetic make-up, osmo-resistance, ability to utilize the substrate and prevailing environmental conditions.

This increase in protein content of the treated-fermented and fermented cassava peels could be attributed to the secretion of some extracellular enzymes such as amylase, linamarase and cellulase by the microorganisms into the fermenting substrate in an attempt to use it as carbon source [24], apparent increase in growth and microbial proliferation of microorganisms in form of single cell protein of the starter culture and normal flora may account for the observed trend in the crude protein [25] and ability (bacterium) to synthesize amino acids and proteins [26]. Oyetayo [27] had reported protein increase of pupuru produced from fermenting cassava. Crude protein 1.46 of starter fermented pupuru with Lactobacillus plantarum had been reported [23]. The result was in agreement with the findings of Sudharmono et al. [7] who reported protein increase in treated cassava peel flour.

The increase in the fat content has been attributed to the lipolytic ability of the microorganisms, secretion of microbial oil, increase in cell growth and utilization of nutrient in the medium by breaking down unsaturated fatty acids into glycerol and pasteurization by boiling which cleaves the protein-lipid as carbohydrate-lipid linkages [28, 29].

The ash composition of food samples is very important in determining mineral contents. An increase in ash content infers that more mineral elements are present in the fermented sample. The increase in ash may be due to the utilization of these salts during fermentation by microorganisms for their metabolic activities. These findings are in line with those of Oboh and Akindahunsi [24] who reported an increase in ash content in cassava products treated with Saccharomyces cerevisiae.

The increase in moisture content of the fermented cassava peels could be attributed to the secretion of free water molecule due to the activities of the fermenting microorganism which had utilized this material during respiration to release more water during the breakdown process in the medium $[25,26]$. This also account for the decrease in carbohydrate content and addition of water to the fermenting substrate [3].

The significant reduction in the crude fiber of the treatedfermented and fermented cassava peel might be attributed to the proliferation and the hydrolytic nature of the fermenting microorganisms which hydrolyzes and metabolize the substrate as carbon source [6, 27].

The decrease in carbohydrate content might be attributed to the leaching of the soluble carbohydrates like sugar into the fermentation medium and as a result of utilization of some of the sugars by fermenting microorganisms for growth and metabolic activities by hydrolysis of starch into glucose as only carbon source [25]. Also, proportionate increase in the protein content in treated-fermented cassava peels could account for the decrease in carbohydrate [10]. This result agrees with the findings earlier reported [3, 30].

Fermentation of cassava and cassava peels had been reported to significantly reduce the antinutrients level [31, 32]. The significant reduction observed in the cyanide content of the treated-fermented cassava peels might be due to the increase in microbial biomass with ability to degrade cyanogenic glycosides (linamarin) in the peels and secretion of extracellular enzyme (linamarase) [3, 13, 33]. The reduction in cyanide content of fermented cassava peels have been reported $[6,34,35]$. The decrease in the phytate content of the fermented cassava peel could be attributed to possible secretion of the enzyme phytase by the microorganisms in the fermenting substrate. This enzyme is capable of hydrolysing phytate thereby decreasing the phytate content of the fermented cassava peels [26]. The pure strains of microbial cultures have been extensively used in improving the nutritional quality of fermented foods.

\section{Conclusions}

In conclusion, the inclusion of adequate inoculum in the fermentation medium with the ability of secreting extracellular enzymes contribute greatly in improving the nutritional composition of cassava wastes under optimum conditions for a desirable product formulation. Therefore, the improvement in nutritional and reduction in anti-nutritional content of the starter treated wastes could be harnessed biotechnologically in industries for livestock feed formulation.

\section{Conflict of Interest}

The authors declared that they have no competing interests.

\section{References}

[1] Arotupin, D. J. (2007). Evaluation of microorganisms from cassava waste water for the production of pectinmethylesterase from Aspergillus repens isolated from cultivated soil. African Journal of Biotechnology, 12: 19911998.

[2] Oluwole, O. S. A., Onabulub, A. O., Mtundac, K. and Mlingid, N. (2007). Characterization of cassava (Manihot esculenta Crantz) varieties in Nigeria and Tanzania, and farmer's perception of toxicity of cassava. Journal of Food Comp and Annal, 20 (7): 559-567.

[3] Adeleke, B. S., Akinyele, B. J., Olaniyi, O. O. and JeffAgboola, Y. A. (2017). Effect of fermentation on chemical composition of fermented cassava Peels. Asian Journal of Plant Science and Research, 7 (1): 31-37.

[4] Afolabi, T. A., Onadeji, R. S., Ogunkunle, O. A. and Bamiro, F. C. (2012). Comparative analysis of the nutritional quality of browse leaves (Spondias mombin and Albizia saman) and tuber peels (yam and cassava) used as ruminant feeds. Ife Journal of Science, 14 (2): 337-344. 
[5] Duru, C. C. and Uma, N. U. (2003). Protein enrichment of solid waste from cocoyam (Xanthosoma sagittifolium (L.) Schott) cormel processing using Aspergillus Oryzae obtained from cormel flour. African Journal of Biotechnology, 2 (8): 228-232.

[6] Oboh G. (2005). Nutrient enrichment of cassava peels using a mixed culture of Saccharomyces cerevisiae and Lactobacillus spp using solid media fermentation techniques. Electronic Journal of Biotechnology, 9 (1): 46-49.

[7] Sudharmono, A., Wilujeng, E. and Dwi, S. (2016). Fermented cassava peel evaluation. International Journal of Chemistry, Technology and Research, 9 (7): 421-426.

[8] Nwafor, O. E., Akpomie, O. and Erijo, P. E. (2015). Effect of fermentation time on the physico-chemical, nutritional and sensory quality of cassava chips (kpo-kpo garri): A traditional Nigerian food. American Journal of Bioscience, 3: 59-63.

[9] De-Gregorio, A., Mandalari, G., Arena, N., Nucita, F., Tripodo, M. M. and Lo-Curto. R. B. (2002). Single cell protein and crude pectinase production by slurry-state fermentation of lemon pulps. Bioresearch and Technology, 83 (2): 89-94.

[10] Okpako, C. E., Ntni, V. E., Osuagwu, A. N. and Obasi, F. I. (2008). Proximate composition and cynanide content of cassava peels fermented with Aspergillus and Lactobacillus rhamnosus. Journal of Food, Agriculture and Environment, 6 (2): 251-255.

[11] Nwokoro, O. and Anya, F. O. (2011) Linamarase enzyme from Lactobacillus delbrueckii NRRLB-763: Purification and some properties of a beta-glucosidase. Journal of Mexican Chemistry and Sociology, 55: 246-250.

[12] Achinewhu, S. C., Barber, L. I. and Ijeoma, I. O. (1998). Physicochemical properties and garification (garri yield) of selected cassava cultivars in Rivers State, Nigeria. Plant Foods and Human Nutrition, 52 (2): 133-140.

[13] Aro, S. O. (2008). Improvement in the nutritive quality of cassava and its by-products through microbial fermentation. African Journal of Biotechnology, 7: 4789-4797.

[14] Obile, E. M., Tano-Debra, K. and Amoa-Awua, W. K. (2004). Souring and breakdown of cyanogenic glucosides during the processing of cassava into akyeke. International Journal of Food Microbiology, 93 (1): 115-121.

[15] Obueh, H. O., Ikenebomeh, M. J. and Kolawole, S. E. (2017). Microbiological and proximate compositions of five cassava fractions subjected to submerged fermentation process. Annals of Food Science and Technology, 18 (1): 70-77.

[16] Oluremi, O. I. A. and Nwosu, A. (2002). Effect of soaked cassava peels on weanling rabbits. Journal of Food Technology, 7 (1): 12-15.

[17] Shimelis, E. A. and Rakshit, S. K. (2008). Influence of natural and controlled fermentations on -galactosides, antinutrients and protein digestibility of beans (Phaseolus vulgaris L.). International Journal of Food Science and Technology, 6: 45-53.

[18] Holt, J. G., Krieg, N. R., Sneath, P. H. A., Stanley. J. T. and Williams, S. T. (1994). Bergey's Manual of Determinative Bacteriology. Williams and Wilkins, Baltimore, Maryland. p. 568

[19] Bonne, D. R., Garrity, G. M., Castenholz, R. W., Brenner, D. J., Krieg, N. R. and Staley, J. T. (2009). Bergey's Manual of Systematic Bacteriology: The Firmicutes. Volume 3, William and Wilkins. USA. p. 1450.
[20] AOAC (2012). Association of Official Analytical Chemists. Official methods of analyses. 21st Edition. Washington DC.

[21] Ahaotu, I., Ogueke, C. C., Owuamanam, C. I., Ahaotu, N. N. and Nwosu, J. N. (2013). Fermentation of under-watered cassava pulp by linamarase producing microorganisms: Effect of nutritional composition and residual cyanide. American Journal of Food and Nutrition, 3: 1-8.

[22] Olufunke, O. E., Ogugua, C. A., Hans, P. B. and Thaddeus, C. E. (2010). Protein enrichment of cassava peel by submerged fermentation with Trichoderma viride (ATCC 36316). African Journal of Biotechnology, 9 (2): 187-194.

[23] Wakil, S. M. and Benjamin, I. B. (2015). Starter developed pupuru: A traditional Africa fermented food from cassava (Manihot esculenta). International Food Research Journal, 22 (6): 2565-2570.

[24] Oboh, G. and Akindahunsi, A. A. (2003). Biochemical changes in cassava products (flour and garri) subjected to Saccharomyces cerevisiae solid media fermentation. Food Chemistry, 82 (4): 559-662.

[25] Aderemi, F. A. and Nworgu, F. C. (2010). Nutritional status of cassava peels and root sieviate biodegraded with Aspergillus niger. Ame-European Journal of Agriculture and Environmental Science, 2 (3): 308-311.

[26] Oboh, G. (2006). Nutrient enrichment of cassava peels using a mixed culture of Saccharomyces cerevisae and Lactobacillus spp. solid media fermentation technique. Electronic Journal of Biotechnology, 9 (1): 46-49.

[27] Oyetayo, V. O. (2006). Nutrient and antinutrient contents of cassava steeped in different types of water for pupuru production. Research Journal of Microbiology, 1 (5): 423-427.

[28] Oseni, O. A. and Kperigin, M. (2010). Studies on biochemical changes in maize wastes fermented with Aspergillus flavus. Biochemistry, 19 (2): 75-79.

[29] Jokotagha, O. A. and Amoo, I. A. (2012). Effect of fermentation on the nutritive value of Aspergillus niger and Aspergillus fumigatus fermented Hura crepitans seed flour. Greener Journal of Physical Science, 2: 63-70.

[30] Madigan, T. M., Martinko, J. M. and Parker, J. (2002). Brock Biology of Microorganisms, Prentice Hall, 9th Edition.

[31] Oboh, G. and Akindahunsi, A. A. (2003). Biochemical changes in cassava products (flour and garri) subjected to Saccharomyces cerevisiae solid media fermentation. Food Chemistry, 82 (4): 559-662.

[32] Aboua, F. (1995). Optimization of traditional fermentation of cassava. Tropical Science, 35: 68-75.

[33] Belewu, M. A. and Musa, A. K. (2003). Effect of selected bacterial strains in the enrichment of cassava waste during solid state fermentation. Tropical Journal of Animal Science, 6 (1): $1-7$.

[34] Asaolu, V. O. (1998). Utilization of cassava peels and Gliricidia sepium in the diet of West African dwarf sheep. M. Phil. thesis, Obafemi Awolowo University, Nigeria.

[35] Tweyongyere, R. and Katongle, I. (2002). Cyanogenic potential of cassava peels and their detoxification for utilization as livestock feed. Veterinary and Human Toxicology, 44 (6): 366-389. 